\title{
The Role of Granzyme B Containing Cells in the Progression of Chronic Obstructive Pulmonary Disease
}

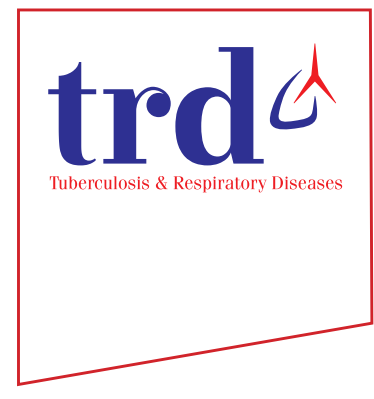

\author{
Won-Dong Kim, M.D. ${ }^{1}{ }^{(i)}$, Hyun-Sook Chi, M.D. ${ }^{2}$, Kang-Hyeon Choe, M.D. ${ }^{3}$, Woo-Sung Kim, M.D. ${ }^{1}$, \\ James C. Hogg, M.D. ${ }^{4}$ and Don D. Sin, M.D. ${ }^{4}$ \\ Departments of ${ }^{1}$ Pulmonary and Critical Care Medicine and ${ }^{2}$ Laboratory Medicine, Asan Medical Center, University of Ulsan \\ College of Medicine, Seoul, ${ }^{3}$ Department of Internal Medicine, Chungbuk National University College of Medicine, Cheongju, \\ Republic of Korea, ${ }^{4}$ The James Hogg iCAPTURE Center for Cardiovascular and Pulmonary Research, St. Paul's Hospital, \\ University of British Columbia, Vancouver, British Columbia, Canada
}

Background: Lung inflammation plays a vital role in the pathogenesis of chronic obstructive pulmonary disease (COPD), but the characteristics of the inflammatory process remain unclear. There is growing interest in the role of granzyme $\mathrm{B}$ (GzmB) because CD8 ${ }^{+} \mathrm{T}$ cells can induce apoptosis of target cells by releasing GzmB, which in turn may cause tissue injury and remodeling. However, GzmB is also expressed by regulatory cells, which are able to suppress $\mathrm{CD}^{+} \mathrm{T}$ cell. The role of $\mathrm{GzmB}^{+}$cells needs to be defined in COPD.

Methods: $\mathrm{GzmB}^{+}$and $\mathrm{CD}^{+}$cells on alveolar wall of surgically resected lungs of microscopically classified 12 nonsmoking control, 12 panlobular emphysema (PLE) and 30 centrilobular emphysema (CLE) subjects were localized by immunohistochemical method. Positively stained cells on alveolar wall were counted and length of corresponding alveolar wall was measured. The results were expressed as mean number of positively stained cells per mm of alveolar wall in each subject.

Results: The number of $\mathrm{GzmB}^{+}$and $\mathrm{CD}^{+}$cells on alveolar wall of CLE was greater than that of control or PLE subjects $\left(\mathrm{p}<0.05\right.$ and $\mathrm{p}<0.001$, respectively). There was a positive relationship between the number of alveolar GzmB ${ }^{+}$cells and forced expiratory volume in 1 second $\left(\mathrm{FEV}_{1}\right)(\mathrm{r}=0.610, \mathrm{p}=0.003)$ in CLE subjects. The number of alveolar GzmB ${ }^{+}$cells progressively decreased with decline of $\mathrm{FEV}_{1}$.

Conclusion: Our finding that number of alveolar $\mathrm{GzmB}^{+}$cells was associated with $\mathrm{FEV}_{1}$ suggests that $\mathrm{GzmB}^{+}$cells might have protective role in the progression of lung destruction and airflow limitation in CLE, which is the predominant emphysema subtype of COPD.

Keywords: Chronic Obstructive Pulmonary Disease; Granzyme B Positive Cell; CD8 ${ }^{+}$T Cell; Centrilobular Emphysema; Regulatory Cells

Address for correspondence: Won-Dong Kim, M.D.

Department of Pulmonary and Critical Care Medicine, Asan Medical Center, University of Ulsan College of Medicine, 88 Olympic-ro 43-gil, Songpa-gu, Seoul 05505, Republic of Korea

Fax: 82-2-6083-4087, E-mail: wdkim2@naver.com

Received: Aug. 6, 2020, Revised: Sep. 13, 2020, Accepted: Oct. 20, 2020, Published online: Oct. 20, 2020

@(t) is identical to the Creative Commons Attribution Non-Commercial License (http://creativecommons.org/licenses/by-nc/4.0/). 


\section{Introduction}

Chronic obstructive pulmonary disease (COPD) is a common, preventable and treatable disease that is characterized by persistent respiratory symptoms and airflow limitation that is due to airway and/or alveolar abnormalities usually caused by significant exposure to noxious particles or gases ${ }^{1}$. COPD is a leading cause of morbidity and mortality worldwide that is associated with significant economic and social burden, which are both substantial and increasing. Tobacco smoking is the most important causative factor, but the marked variability in lung function in people with similar cigarette smoking histories suggests an important role for genetics and other factors in COPD.

Lungs from patients with COPD are characterized by inflammatory cellular infiltration and remodeling of small airways with thickening of their walls and narrowing of their lumen. The histological features associated with these changes include inflammatory cell infiltration of the alveolar walls, as well as destruction and enlargement of air spaces beyond the terminal bronchioles. The mixture of small airway obstruction and parenchymal destruction of emphysema contributes to airflow limitation in $\mathrm{COPD}^{2}$.

It is well accepted that lung inflammation plays an important role in the pathogenesis of COPD, but the type of inflammatory cells that participate in this destruction remains unclear. It was reported that smokers who develop chronic airflow limitation have an increased number of $\mathrm{CD}^{+} \mathrm{T}$ lymphocytes in the peripheral airways ${ }^{3}$, supporting the important role of $\mathrm{CD}^{+} \mathrm{T}$ lymphocyte in the pathogenesis of COPD. An increase in apoptosis of airway epithelial cell has also been suggested to contribute to COPD pathogenesis ${ }^{4}$. The role of granzyme $\mathrm{B}(\mathrm{GzmB})$ was proposed ${ }^{5}$, because $\mathrm{CD} 8^{+} \mathrm{T}$ cells are able to induce apoptosis of target cells by releasing GzmB and non-specifically released GzmB may accumulate in the extracellular milieu, leading to tissue destruction and parenchymal remodeling ${ }^{6}$. Indeed, GzmB levels as well as T cells expressing GzmB are increased in bronchoalveolar lavage (BAL) fluid of COPD patients ${ }^{7}$. However, to our knowledge, the localization of $\mathrm{GzmB}^{+}$cells on the alveolar wall has not been reported in emphysema. On the other hand, GzmB has been shown to be expressed in not only $\mathrm{CD}^{+} \mathrm{T}$ cells, but also in many other cells such as regulatory cells ${ }^{8}$, which are able to suppress CD8 T cells.

The role of alveolar $\mathrm{GzmB}^{+}$cells in centrilobular emphysema, which is an important component of COPD is largely unknown. In this study, we explored the role of $\mathrm{GzmB}^{+}$cells in the process of lung destruction by determining the number of alveolar $\mathrm{GzmB}^{+}$cells according to the degree of airflow limitation in anatomically documented centrilobular emphysematous lungs.

\section{Materials and Methods}

\section{Patient population and specimens}

The study group consisted of 12 nonsmoker subjects who had normal spirometry and did not demonstrate any microscopic evidence of emphysema in their lungs, and 42 subjects

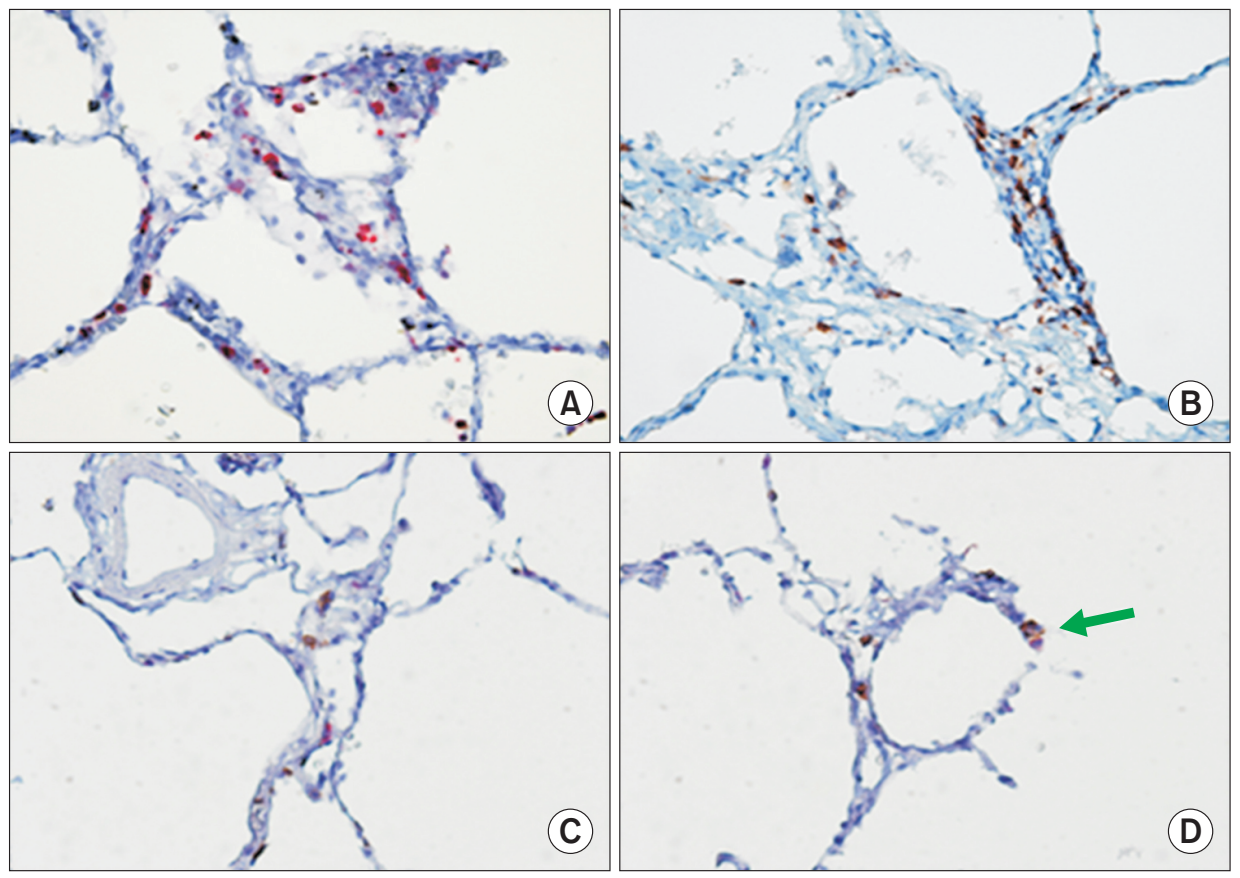

Figure 1. Immunohistochemical staining of $\mathrm{GzmB}^{+}$and $\mathrm{CD}^{+}$cells on alveolar wall of centrilobular emphysema subjects ( $\times 400)$. (A) $\mathrm{GzmB}^{+}$cells (red color). (B) $\mathrm{CD}^{+}$cells (brown color). (C) Separate $\mathrm{GzmB}^{+}$cell (red color) and $\mathrm{CD}^{+}$cell (brown color). (D) Compared to pure red color of $\mathrm{GzmB}^{+}$cell and brown color of $\mathrm{CD}^{+}$cell as shown in $\mathrm{A}$ and $\mathrm{B}$, mixed color of red and brown suggests dually stained cell for GzmB and CD8 (arrow). GzmB: granzyme B. 
with microscopic emphysema, including 12 with pure panlobular emphysema (PLE) without $\alpha 1$-antitrypsin deficiency and 30 with pure centrilobular emphysema (CLE). Specimens were obtained from two groups of subjects: 27 Asian (6 control, 6 PLE, and 15 CLE subjects) from Asan Medical Center, Seoul, Korea and 27 Caucasian (6 control, 6 PLE, and 15 CLE subjects) from St. Paul's Hospital, Vancouver, Canada, who underwent lung resection surgery for lung tumor or lung transplantation. All subjects gave informed consent for their participation in the study. The protocol was approved by the Institutional Review Board of the Asan Medical Center (IRB No. 2006-0218) and the University of British Columbia/ Providence Health Care Research Ethics Board (IRB No. H0700211).

\section{Histologic analysis}

The lungs were processed for histological examination and emphysema was diagnosed based on the microscopic criteria as previously described ${ }^{9,10}$. The diagnosis of PLE was made when secondary lobules were homogeneously enlarged from the center to the periphery. Microscopic CLE was diagnosed when sharply demarcated emphysematous spaces, separated from the acinar periphery by intact alveolar ducts and sacs of normal size, were observed. Mean linear intercept (Lm) was measured and the coefficient of variation (CV) (standard deviation/mean) of interalveolar wall distances was determined to define the uniformity of lung enlargement in PLE and nonuniformity in CLE.

A rabbit polyclonal antibody anti-GzmB (Cell Marque,

Table 1. Clinical characteristics of study subjects

\begin{tabular}{|c|c|c|c|c|}
\hline & Nonsmoker control & PLE & CLE & p-value \\
\hline No. of subjects & 12 & 12 & 30 & \\
\hline \multicolumn{5}{|c|}{ Demographic characteristics } \\
\hline Age, yr & $53.1 \pm 15.8$ & $60.6 \pm 7.0$ & $68.3 \pm 7.7$ & 0.063 \\
\hline Male sex & 5 & 6 & 23 & \\
\hline \multicolumn{5}{|l|}{ Smoking status } \\
\hline Nonsmoker & 12 & 2 & 1 & \\
\hline Ex-smoker & 0 & 7 & 10 & \\
\hline Current smoker & 0 & 3 & 19 & \\
\hline Amount, pack-years & 0 & $28.9 \pm 20.0$ & $46.6 \pm 26.9$ & 0.001 \\
\hline \multicolumn{5}{|c|}{ Functional characteristics } \\
\hline \multicolumn{5}{|c|}{ GOLD stage } \\
\hline Unclassified & 0 & 1 & 2 & \\
\hline 0 & 12 & 3 & 12 & \\
\hline 1 & 0 & 2 & 6 & \\
\hline 2 & 0 & 3 & 5 & \\
\hline 3 & 0 & 0 & 3 & \\
\hline 4 & 0 & 3 & 2 & \\
\hline $\mathrm{FEV}_{1} / \mathrm{FVC}, \%$ & $80.6 \pm 5.2$ & $59.7 \pm 19.3$ & $65.9 \pm 14.8$ & 0.001 \\
\hline $\mathrm{FEV}_{1}, \%$ of predicted & $98.5 \pm 11.8$ & $69.6 \pm 33.3$ & $77.1 \pm 24.0$ & 0.010 \\
\hline $\mathrm{DL}_{\mathrm{co}}, \%$ of predicted & $105.3 \pm 27.1$ & $84.3 \pm 35.1$ & $80.8 \pm 30.4$ & 0.023 \\
\hline TLC, \% of predicted & $101.6 \pm 31.5$ & $113.8 \pm 20.7$ & $110.4 \pm 15.3$ & 0.424 \\
\hline $\mathrm{RV}, \%$ of predicted & $115.1 \pm 24.2$ & $136.5 \pm 39.3$ & $129.8 \pm 46.9$ & 0.399 \\
\hline
\end{tabular}

Values are presented as mean $\pm \mathrm{SD}$ or number.

GOLD stages are defined as follow: unclassified ( $\mathrm{FEV}_{1} / \mathrm{FVC} \geq 0.70, \mathrm{FEV}_{1}<80 \%$ of predicted value), GOLD stage 0 ( $\mathrm{FEV}_{1} / \mathrm{FVC} \geq 0.70, \mathrm{FEV}_{1} \geq 80 \%$ of predicted value), GOLD stage $1\left(\mathrm{FEV}_{1} / \mathrm{FVC}<0.70, \mathrm{FEV}_{1} \geq 80 \%\right.$ of predicted value), GOLD stage $2\left(\mathrm{FEV}_{1} / \mathrm{FVC}<0.70, \mathrm{FEV}_{1}<80 \%\right.$, but $>50 \%$ of predicted value), GOLD stage $3\left(\mathrm{FEV}_{1} / \mathrm{FVC}<0.70, \mathrm{FEV}_{1}<50 \%\right.$, but $>30 \%$ of predicted value), and $\mathrm{GOLD}$ stage $4\left(\mathrm{FEV}_{1} / \mathrm{FVC}<0.70, \mathrm{FEV}_{1} \leq 30 \%\right.$ of predicted value).

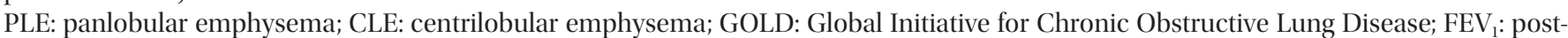
bronchodilator forced expiratory volume in 1 second; FVC: forced vital capacity; $\mathrm{DL}_{\mathrm{co}}$ : diffusing capacity for carbon monoxide; TLC: total lung capacity; RV: residual volume; SD: standard deviation. 
Rocklin, CA, USA) and a monoclonal mouse antibody antihuman CD8 (DakoCytomation, Glostrup, Denmark) were used to identify $\mathrm{GzmB}^{+}$(Figure $1 \mathrm{~A}$ ) and $\mathrm{CD}^{+}$cells (Figure 1B) on alveolar wall, respectively. Immunostaining was performed using an automated immunostaining device BenchMark (Ventana Medical Systems Inc., Tucson, AZ, USA).

Positively stained cells on alveolar wall were counted and the length of corresponding alveolar wall was measured using digitally generated images at a magnification of $\times 400$ with Image Pro Plus digital-image-analysis software (Media Cybernetics, Inc., Silverspring, MD, USA). At least 30 randomly selected fields were examined for each subject by choosing every 5 th field in the microscopic images. The arithmetic mean of the measured length of alveolar walls was $12.6 \pm 1.0 \mathrm{~mm}$ per subject. The results were expressed as mean number of positively stained cells per $\mathrm{mm}$ of alveolar wall in each subject. Measurement of volume fraction $(\mathrm{VV})$ of $\mathrm{GzmB}^{+}$and $\mathrm{CD} 8^{+}$cells in small airway wall of the study subjects were reported in the previously published paper ${ }^{10}$.

\section{Statistical analysis}

Results are expressed as mean \pm standard deviation. The nonparametric Kruskal-Wallis test was used to evaluate significant differences among the groups; when significance was found, post hoc testing between groups was performed using the nonparametric Mann-Whitney test. The correlation between the variables was determined with the use of nonparametric Spearman's rank correlation. All statistical analyses were performed using GraphPad Prism version 5.04 software (GraphPad Software, Inc., La Jolla, CA, USA). p $<0.05$ was considered significant.

\section{Results}

\section{Clinical characteristics of study subjects and morphometric data of their lung tissues}

Clinical characteristics of the subjects, including the results of pulmonary function tests, are presented in Table 1. All subjects with emphysema were smokers, except one CLE and two PLE subjects. PLE subjects had fewer pack-years of smoking compared to CLE, probably because of two nonsmokers and a relatively high proportion of ex-smokers in the PLE group. CLE and PLE subjects had lower post bronchodilator forced expiratory volume in 1 second $\left(\mathrm{FEV}_{1}\right)(\mathrm{p}<0.005$ and $\mathrm{p}<0.05$, respectively) and $\mathrm{FEV}_{1} /$ forced vital capacity $(\mathrm{p}<0.001$ and $\mathrm{p}<0.005$, respectively) compared to control subjects.

Morphometric data of lung tissues of the study subjects are presented in Table 2. Lm was greater in CLE $(p<0.001)$ and PLE $(\mathrm{p}<0.03)$ compared to that in control subjects. CV (standard deviation/mean) of interalveolar wall distances was higher in CLE compared to that in control $(\mathrm{p}<0.001)$ or PLE subjects $(\mathrm{p}<0.005)$, providing objective evidence of nonuniform enlargement of alveolar wall in CLE. Small airway wall thickness was greater in CLE compared to that in control subjects $(\mathrm{p}<0.001)$.

\section{Number of alveolar $\mathrm{GzmB}^{+}$and $\mathrm{CD8}^{+}$cells in study subjects}

CLE had greater numbers of $\mathrm{GzmB}^{+}(\mathrm{p}<0.05$, respectively $)$ (Figure $2 \mathrm{~A}$ ) and $\mathrm{CD}^{+}$cells ( $<<0.001$, respectively) (Figure $2 \mathrm{~B}$ ) compared to control or PLE subjects (Table 2).

Table 2. Morphometric characteristics of lung tissues of study subjects

\begin{tabular}{|c|c|c|c|c|}
\hline & Nonsmoker control & PLE & CLE & p-value \\
\hline No. of subjects & 12 & 12 & 30 & \\
\hline $\mathrm{Lm}, \mathrm{mm}$ & $0.191 \pm 0.046^{*}$ & $0.275 \pm 0.095$ & $0.274 \pm 0.055$ & 0.002 \\
\hline CV of IAWD & $0.281 \pm 0.068$ & $0.319 \pm 0.182$ & $0.517 \pm 0.198^{\dagger}$ & 0.001 \\
\hline Airway wall thickness, mm & $0.063 \pm 0.017$ & $0.079 \pm 0.029$ & $0.093 \pm 0.021^{*}$ & 0.002 \\
\hline \multicolumn{5}{|l|}{ Small airway wall } \\
\hline Vv of CD8 ${ }^{+}$cells, $\%$ & $1.09 \pm 0.47$ & $1.32 \pm 0.46$ & $2.14 \pm 0.50$ & 0.001 \\
\hline Vv of GzmB ${ }^{+}$cells, \% & $1.26 \pm 0.60$ & $1.24 \pm 0.65$ & $2.74 \pm 1.10$ & 0.001 \\
\hline \multicolumn{5}{|l|}{ Alveolar wall } \\
\hline $\mathrm{CD8}^{+}$cells $/ \mathrm{mm}$ & $1.69 \pm 1.59$ & $2.03 \pm 2.76$ & $7.70 \pm 3.37^{\S}$ & 0.001 \\
\hline $\mathrm{GzmB}^{+}$cells $/ \mathrm{mm}$ & $2.97 \pm 2.91$ & $2.69 \pm 3.05$ & $5.18 \pm 3.39^{1}$ & 0.016 \\
\hline
\end{tabular}

Values are presented as mean \pm SD.

${ }^{*} \mathrm{p}<0.03$ vs. PLE and CLE subjects. ${ }^{\dagger} \mathrm{p}<0.005$ vs. control and PLE subjects. ${ }^{\dagger} \mathrm{p}<0.001$ vs. control subjects. ${ }^{\S} \mathrm{p}<0.001$ vs. control and PLE subjects. " $\mathrm{p}<0.05$ vs. control and PLE subjects.

PLE: panlobular emphysema; CLE: centrilobular emphysema; Lm: mean linear intercept; CV: coefficient of variation; IAWD: interalveolar wall distance; Vv: volume fraction; GzmB: granzyme B. 

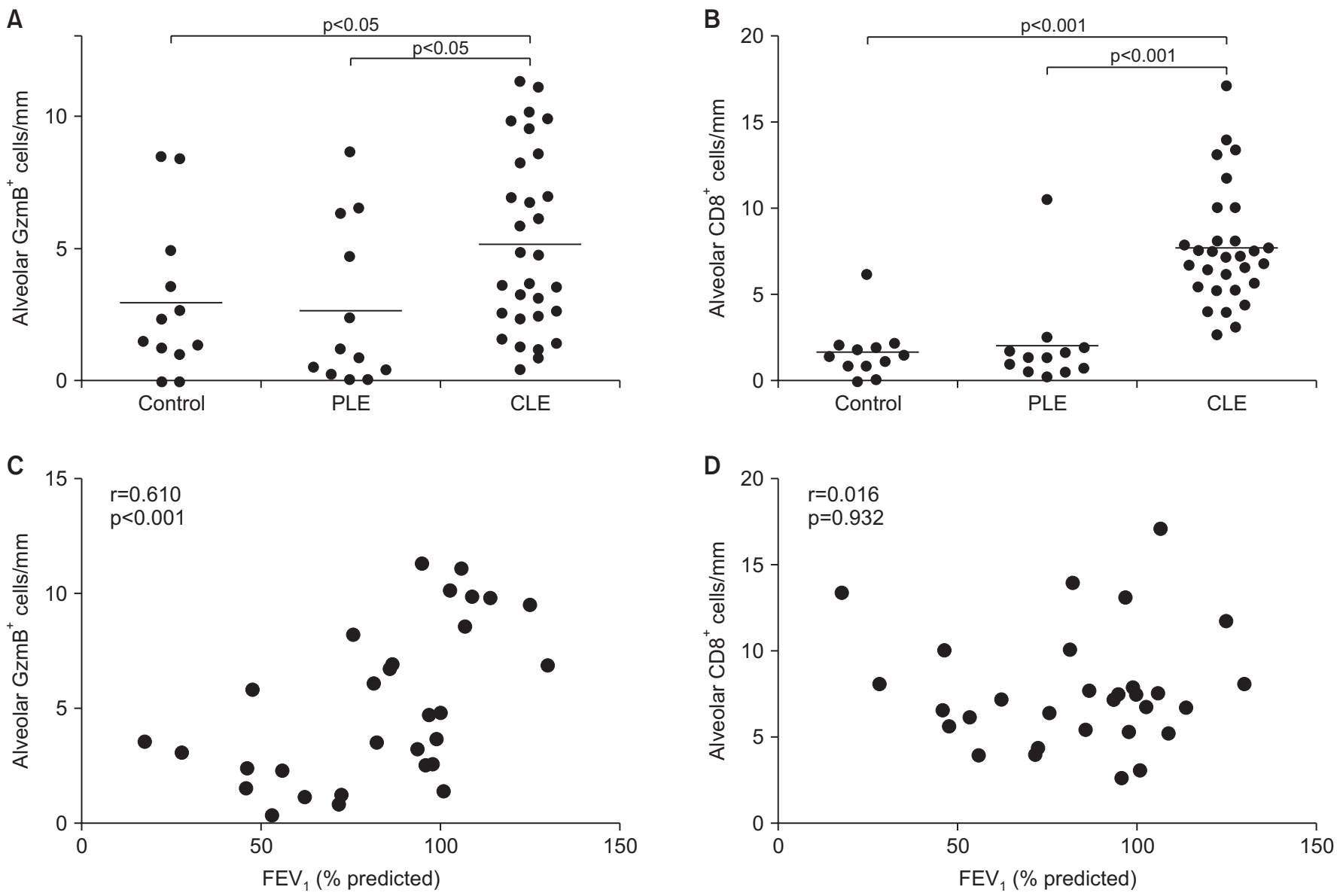

Figure 2. Number of alveolar GzmB ${ }^{+}$(A) and $\mathrm{CD8}^{+}$cells (B) in study subjects. (A) Alveolar GzmB ${ }^{+}$cells in CLE are significantly greater than that in control or PLE subjects. (B) Number of alveolar CD8 ${ }^{+}$cells in CLE are also significantly greater than that in control or PLE subjects.

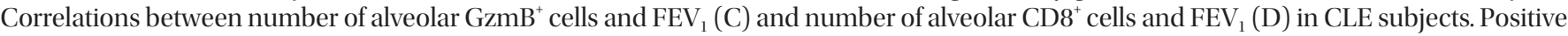
relationship between number of alveolar $\mathrm{GzmB}^{+}$cells and $\mathrm{FEV}_{1}(\mathrm{C})$ and no relationship between number of alveolar $\mathrm{CD}^{+}$cells and FEV $\mathrm{F}_{1}(\mathrm{D})$ in CLE subjects. CLE: centrilobular emphysema; $\mathrm{FEV}_{1}$ : postbronchodilator forced expiratory volume in 1 second; GzmB: granzyme B; PLE: panlobular emphysema.

\section{Relationships of alveolar $\mathrm{GzmB}^{+}$and $\mathrm{CD8}^{+}$cells with $\mathrm{FEV}_{1}$ in CLE subjects}

The correlation between the number of alveolar $\mathrm{GzmB}^{+}$ cells and $\mathrm{FEV}_{1}$ was significant $(\mathrm{r}=0.610, \mathrm{p}<0.001)$ (Figure 2C). However, that between the number of alveolar $\mathrm{CD}^{+}$cells and $\mathrm{FEV}_{1}$ was not significant $(\mathrm{r}=0.016, \mathrm{p}=0.932)$ (Figure 2D).

\section{Number of alveolar $\mathrm{GzmB}^{+}$and $\mathrm{CDB}^{+}$cells according to severity of airflow limitation in CLE subjects}

The subjects with $\mathrm{FEV}_{1} 80 \%$ or above had higher numbers of $\mathrm{GzmB}^{+}$cells compared to subjects with $\mathrm{FEV}_{1}$ below $80 \%$ $(\mathrm{p}<0.005)$ (Figure $3 \mathrm{~A})$, indicating alveolar $\mathrm{GzmB}^{+}$cells were increased in subjects with preserved $\mathrm{FEV}_{1}$. The number of $\mathrm{CD}^{+}$ cells was not significantly different between the two groups ( $>0.05)$ (Figure 3B).

\section{Relationship between number of alveolar $\mathrm{GzmB}^{+}$ cells and volume fraction of those cells in the small airway wall in CLE subjects}

The correlation between the number of alveolar $\mathrm{GzmB}^{+}$ cells and volume fraction of those cells in the small airway wall was significant $(\mathrm{r}=0.659, \mathrm{p}<0.001)$ (Figure $3 \mathrm{C}$ ), suggesting a possible role of $\mathrm{GzmB}^{+}$cells in the progression of both emphysema and small airway disease in CLE subjects, but this relationship was not significant for $\mathrm{CD}^{+}$cells $(\mathrm{r}=-0.022$, $\mathrm{p}=0.906$ ) (Figure 3D).

\section{Discussion}

In the present study we demonstrated that the number of $\mathrm{GzmB}^{+}$cells on the alveolar wall of subjects with CLE is direct- 
A

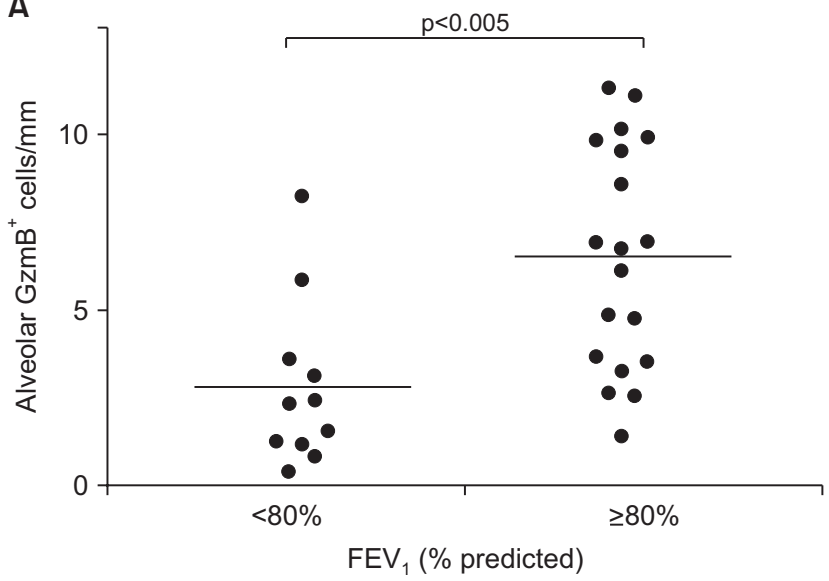

C

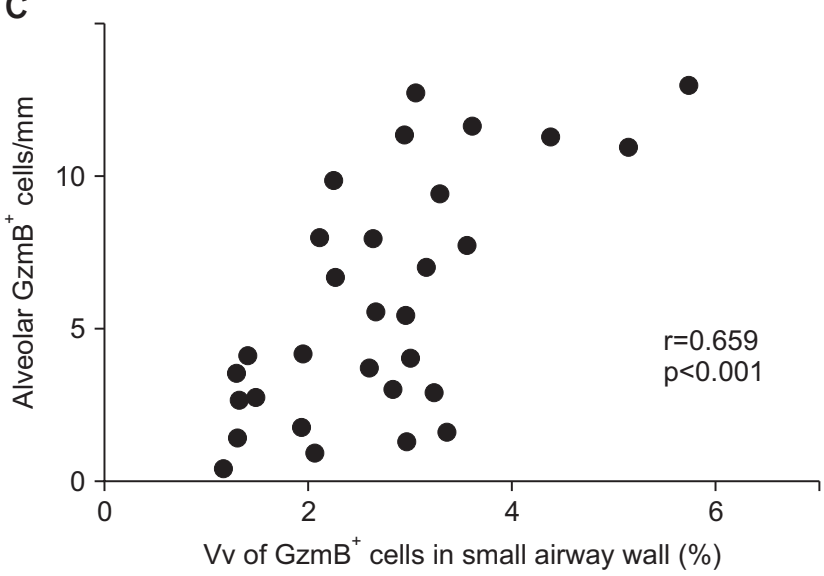

B

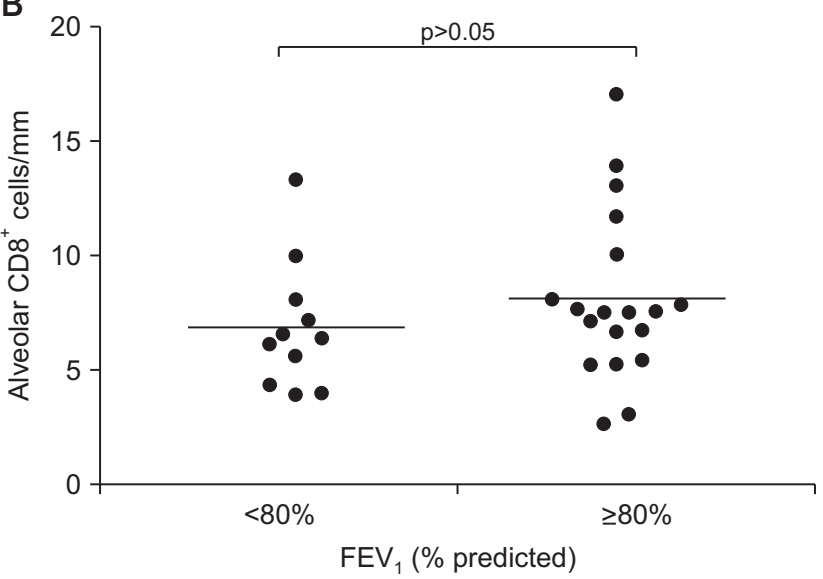

D

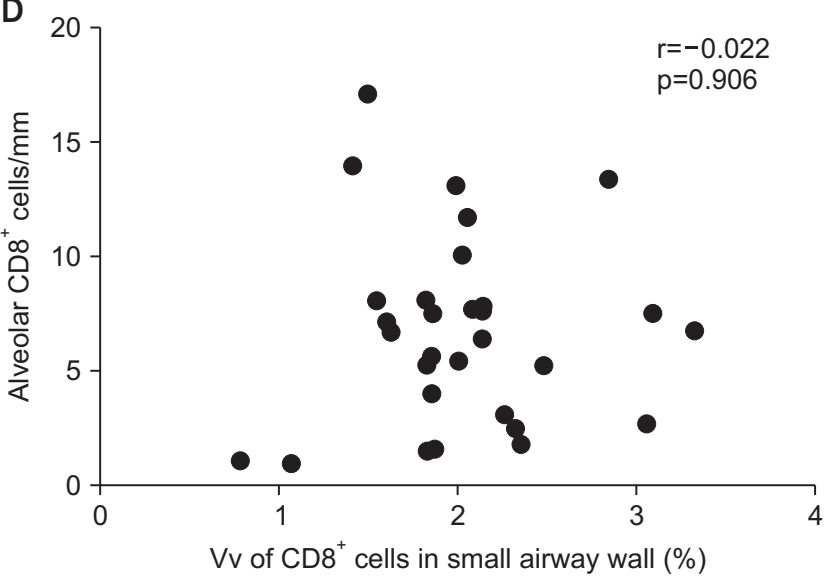

Figure 3. Number of $\mathrm{GzmB}^{+}(\mathrm{A})$ and $\mathrm{CD}^{+}$cells (B) in study subjects with $\mathrm{FEV}_{1}$ below $80 \%$ predicted and those with $\mathrm{FEV}_{1} 80 \%$ or above in CLE subjects. (A) Significantly higher number of alveolar $\mathrm{GzmB}^{+}$cells in subjects with $\mathrm{FEV}_{1} 80 \%$ or above than those with $\mathrm{FEV}_{1}$ below $80 \%$ in CLE subjects. (B) No difference in number of alveolar $\mathrm{CD}^{+}$cells between the two groups. Correlations between number of alveolar $\mathrm{GzmB}^{+}$ cells and volume fraction of those cells in small airway wall (C) and correlations between number of alveolar CD $8^{+}$cells and volume fraction of those cells in small airway wall (D) in CLE subjects. (C) Positive relationship between number of alveolar GzmB ${ }^{+}$cells and volume fraction of those cells in small airway wall, suggesting common associated role of $\mathrm{GzmB}^{+}$cells in emphysema and small airway disease in CLE subjects. (D) No relationship between number of alveolar $\mathrm{CD}^{+}$cells and volume fraction of those cells in small airway wall. CLE: centrilobular emphysema; $\mathrm{FEV}_{1}$ : postbronchodilator forced expiratory volume in 1 second; GzmB: granzyme B; Vv: volume fraction.

ly related to $\mathrm{FEV}_{1}$. We also showed that alveolar $\mathrm{GzmB}^{+}$and $\mathrm{CD}^{+}$cells are present in greater numbers in CLE compared with those in control or PLE lungs. Notably, on dual staining for GzmB and CD8, not all GzmB ${ }^{+}$cells were CD8 positive and not all CD8 ${ }^{+}$cells were GzmB positive (Figure 1C, D).

COPD is not a single disease entity and pathologically it consists of emphysema and small airway disease. CLE is the most common subtype of emphysema in COPD ${ }^{11,12}$ and this type of emphysema is associated with small airway disease ${ }^{9,13,14}$.

A few morphologic studies ${ }^{15-18}$ have attempted to directly describe the nature of inflammatory cells on the alveolar wall of emphysema, where actual lung destruction occurs. Increased number of $\mathrm{CD} 8^{+}$cells on alveolar wall was reported in emphysema, but the numbers of natural killer cell, which is another source of GzmB, were not increased in this study ${ }^{17}$.
Apoptosis induced by cytolytic function of $\mathrm{CD}^{+} \mathrm{T}$ cell was suggested as one of the mechanisms for lung destruction.

The role of autoimmunity in the pathogenesis of COPD is increasingly recognized ${ }^{19}$. It was suggested that $\mathrm{CD}^{+} \mathrm{T}$ cells are recruited upon tobacco-modified self-antigenic stimulation and activated to become $\mathrm{GzmB}^{+}$cells in the pathogenesis of COPD. The present result demonstrating increased number of $\mathrm{CD}^{+} \mathrm{T}$ cells in CLE suggests involvement of these cells in lung destruction. However, localization of $\mathrm{GzmB}^{+}$cell, which is a marker of activated cytolytic $\mathrm{CD}^{+} \mathrm{T}$ cell, on the alveolar wall of emphysema has not been reported and actual role of $\mathrm{GzmB}^{+}$cell in COPD is not known.

The present study showed a higher number of alveolar $\mathrm{GzmB}^{+}$cells in mild emphysema and a lower number of $\mathrm{GzmB}^{+}$cells in severe one. This trend was also present in vol- 
ume fraction of $\mathrm{GzmB}^{+}$cells in the small airway wall of CLE subjects ${ }^{10}$. In addition, lung tissue expression of GzmB was also positively correlated with $\mathrm{FEV}_{1}$ in smokers ${ }^{10}$. With this result we were not certain whether $\mathrm{GzmB}^{+}$cells are effector of cytolysis in the pathogenesis of emphysema or controllers over the effector $\mathrm{CD}^{+} \mathrm{T}$ cells that cause tissue damage in these emphysema subjects.

In a previous report ${ }^{10}$, we found that cases with mild airflow limitation may represent early stages of CLE, therefore they demonstrated increased volume fraction of $\mathrm{GzmB}^{+}$cells for active cytolytic function in the small airway wall. However, in order to explore the role of $\mathrm{GzmB}^{+}$cells as an effector of cytolysis, identification of $\mathrm{GzmB}^{+} \mathrm{CD8}^{+} \mathrm{T}$ cell in early stages of lung destruction would be necessary. To our knowledge, no such study has been reported in early COPD subjects.

It was shown that only recently activated $\mathrm{CD} 8^{+} \mathrm{T}$ cells are capable of GzmB production ${ }^{20}$. In chronic infections and cancer, T cells are exposed to persistent antigen and/or inflammatory signals and $\mathrm{T}$ cell is exhausted to manifest progressive loss of effector functions ${ }^{21}$. This fact suggests that GzmB containing cells in "old" COPD subjects may not necessarily be $\mathrm{CD}^{+} \mathrm{T}$ cells. Consistent with this notion, we showed that not all $\mathrm{GzmB}^{+}$cells were CD8 positive and not all $\mathrm{CD} 8^{+}$cells were GzmB positive on dual staining. Additionally, the previously reported result showed that volume fraction of $\mathrm{GzmB}^{+}$cells $(2.70 \pm 1.08 \%)$ was greater than that of $\mathrm{CD} 8^{+}$cells $(2.02 \pm 0.56 \%)$ in the small airway wall of the same CLE subjects $(\mathrm{p}=0.006)^{10}$.

Regulatory $\mathrm{T}$ (Treg) cells play a crucial role in maintaining peripheral tolerance and preventing autoimmunity. It was reported that COPD patients had fewer BAL fluid Treg cells than healthy smokers and it was hypothesized that an insufficient number of regulatory $\mathrm{T}$ cells to $\mathrm{CD} 8^{+} \mathrm{T}$ cell ratio may contribute to $\mathrm{COPD}^{22}$. Significantly fewer Treg cells were present in the resected lungs of subjects with emphysema relative to control subjects ${ }^{23}$. COPD subjects showed decreased Treg cells in BAL fluid and they displayed positive correlations with $\mathrm{FEV}_{1}^{24}$. Immunohistochemical study of lung tissue of resected lungs also showed decreased number of Treg cells in the small airways of COPD and they positively correlated with $\mathrm{FEV}_{1}^{25}$.

GzmB was not expressed in naïve Treg cells, but was highly expressed in Treg cells in the tumor environment in animal study $^{26}$. It was found that tumor cells induced GzmB expression in Treg cells, which in turn utilized GzmB to suppress tumor clearance mediated by $\mathrm{CD}^{+} \mathrm{T}$ cells. In human endometrial carcinoma, Treg cells in the tumor microenvironment can express significantly higher levels of GzmB. GzmB was rarely expressed by $\mathrm{CD}^{+} \mathrm{T}$ cell-derived tumor-infiltrating lymphocytes ${ }^{27}$. One of mechanisms by which Treg cells control the immune response is by inhibiting cytolysis of effector cell through the production of granzymes ${ }^{28}$. In an animal study, depletion of Treg cells before respiratory syncytial virus challenge led to a marked increase in the influx of inflamma- tory cells into the lung, and boosting Treg numbers reduced pathology. The ability of Treg cells to regulate lung inflammation depended on their ability to produce $\mathrm{GzmB}^{8}$. In addition to Treg cells, human plasmacytoid dendritic cell (pDC) can be an abundant source of GzmB and $\mathrm{GzmB}^{+} \mathrm{pDC}$ potentially suppresses T-cell proliferation in a GzmB-dependent manner $^{29}$. Also it was reported that the microenvironment of various solid tumors includes B cells that express GzmB, which suppress T-cell proliferation by GzmB-dependent degradation of the T-cell receptor ${ }^{30}$. Because Treg cell, pDC and B cell are known to modulate $\mathrm{T}$ effector cells by a GzmB-dependant mechanism, it was hypothesized that GzmB may be a common effector molecule of human regulatory cells in general ${ }^{30}$. Together, these findings raise the possibility that most of alveolar $\mathrm{GzmB}^{+}$cells in the present older emphysema subjects could be GzmB expressing regulatory cells.

The finding of higher numbers of alveolar $\mathrm{GzmB}^{+}$cells in older CLE subjects with relatively preserved $\mathrm{FEV}_{1}$ in the present study suggests that greater GzmB expressing regulatory cells might have suppressed more effector T cells, resulting in less lung destruction and relative preservation of lung function in these CLE subjects.

GzmB is a common mediator for $\mathrm{CD}^{+}$effector $\mathrm{T}$ cell and regulatory cells which suppress effector T cell; therefore, GzmB may play a dual opposing role in target cell destruction. It was reported that in immune surveillance, GzmB, the most potent cytotoxic molecules, act mainly as an antitumoral and anti-infectious factor, but when expressed by immune regulatory cells they may contribute to immune evasion of specific cancer types $^{31}$.

Although $\mathrm{GzmB}^{+} \mathrm{CD}^{+} \mathrm{T}$ cell is presumed to have a role as an effector cell in early stages of COPD, it remains a mystery as to how very low GzmB in $\mathrm{CD}^{+}$effector $\mathrm{T}$ cell can exert a cytolytic function. It is known that $\mathrm{CD}^{+} \mathrm{T}$ lymphocytes express both GzmB and granzyme A (GzmA), but Treg cells induce expression of GzmB only ${ }^{32}$. Although there are several mechanisms by which $\mathrm{CD}^{+}$effector $\mathrm{T}$ cells exert cytotoxic action, there was a report that $\mathrm{CD}^{+} \mathrm{T}$ cells lacking GzmB retain cytotoxic activity through the action of the GzmA in an animal study $^{33}$. Also it was reported that in the lungs of very severe COPD subjects who underwent lung transplantation, bronchiolar epithelium stained positive for GzmA, but not for GzmB and intense staining for GzmA in type II pneumocytes ${ }^{34}$. This extracellularly released GzmA suggests the finding that GzmA pathway is activated and GzmA is resultantly leaked out. Thus the low alveolar $\mathrm{GzmB}^{+}$cells in severe CLE observed in the present study might have played reduced suppressive action on effector $\mathrm{CD} 8^{+} \mathrm{T}$ cells, which in turn may have enhanced cytolytic effector T cell function through GzmA pathway, resulting in increased lung damage. However, it is not known what causes low GzmB in severe COPD. One possibility is that GzmB related genetic influence modulates GzmB at the cellular level, but further study is needed to validate the reason. 
We posit that the role of alveolar $\mathrm{CDB}^{+} \mathrm{T}$ and $\mathrm{GzmB}^{+}$cells in the pathogenesis and progression of emphysema is different in CLE compared with PLE. We observed an increase in alveolar $\mathrm{CD}^{+} \mathrm{T}$ and $\mathrm{GzmB}^{+}$cells in CLE (a tobacco-related emphysema) compared with control or PLE lungs. Although naïve, quiescent $\mathrm{T}$ cells cannot egress directly from blood into lung parenchyma, activated $\mathrm{T}$ cells by antigen-bearing dendritic cells can be drawn into lung tissue ${ }^{19}$. It should be noted that cytolytic T cell and Treg cell activation is antigenspecific. Thus, we speculate that these cells play an important role in the pathogenesis of CLE but not PLE. In contrast to CLE, whose emphysematous lesions are small and discrete, PLE lungs show diffuse emphysematous changes throughout the secondary lobules. PLE may be driven by an imbalance in the proteolytic-antiproteolytic enzymatic activity in the alveolar units and thus may be less dependent on T cell biology or cell-mediated pathology. Therefore CLE and PLE are likely different diseases even though clinically they ultimately lead to airflow limitation. Future research study on COPD should be done according to the subtypes of emphysema. This study showed that some mild emphysema cases can have no airflow limitation even though they have definite anatomic emphysema on microscopic examination. Also it is notable that $\mathrm{GzmB}^{+}$cell might have common associated role in the progression of both emphysema and small airway disease in CLE.

There are several limitations to the study. We included both Asian and Caucasian subjects, which might have introduced confounding by ethnicity, but there were no differences in the number of alveolar $\mathrm{GzmB}^{+}$and $\mathrm{CD}^{+}$cells between the two races in control and PLE subjects. The recruited number of study subjects was not large enough to validate the results, but it was due to innate complexity of morphometric study of human lungs to be performed. Another limitation was that this study was cross-sectional. Further, although the age distribution of mild and severe emphysema subjects was not significantly different, we did not have accurate information on the duration or intensity of smoking for our cohort. The mean age of cases with $\mathrm{FEV}_{1}$ below $80 \%$ predicted $\left(\mathrm{n}=11, \mathrm{FEV}_{1}\right.$ $52.7 \pm 18.2 \%$ ) was $62.5 \pm 6.0$ years and that of cases with $\mathrm{FEV}_{1}$ $80 \%$ or above $\left(\mathrm{n}=19, \mathrm{FEV}_{1} 100.6 \pm 12.9 \%\right)$ was $62.9 \pm 8.8$ years. Given a similar age distribution, we postulate that the differences in the severity of airflow limitation represent differences in individual's genetic susceptibility to COPD as proposed by a previous report ${ }^{19}$. We did not have quantitative data for dual staining of $\mathrm{GzmB}^{+}$and $\mathrm{CD} 8^{+}$cells because our primary aim was to determine the number of alveolar $\mathrm{GzmB}^{+}$and $\mathrm{CD}^{+}$ cells according to the severity of airflow limitation in CLE. Also we did not have data on dual staining for Treg and GzmB, because it was beyond the purview of the present study. Additional studies will be required to quantitate these cells in lungs of COPD patients.

In conclusion, this study shows that $\mathrm{GzmB}^{+}$and $\mathrm{CD} 8^{+}$cells are upregulated on the alveolar wall of CLE compared to control or PLE lungs. There is a strong positive relationship between the number of alveolar $\mathrm{GzmB}^{+}$cells and $\mathrm{FEV}_{1}$ in CLE subjects. These data suggest that $\mathrm{GzmB}^{+}$cell may play an important role in determining the extent of lung destruction and degree of airflow limitation in centrilobular type of emphysema.

\section{Authors' Contributions}

Conceptualization: Kim WD, Hogg JC. Methodology: Chi HS. Investigation: Choe KH, Kim WS, Kim WD. Writing - original draft preparation: Kim WD. Writing - review and editing: Sin DD, Hogg JC. Approval of final manuscript: all authors.

\section{Conflicts of Interest}

No potential conflict of interest relevant to this article was reported.

\section{Funding}

This work was supported by the Faculty Academic Support Grant at the Asan Medical Center, Seoul, Republic of Korea.

\section{References}

1. Global Initiative for Chronic Obstructive Lung Disease (GOLD). Global strategy for the diagnosis, management, and prevention of chronic obstructive pulmonary disease (2020 report) [Internet]. Fontana: GOLD; 2020 [cited 2020 May 9]. Available from: http://www.goldcopd.org.

2. Hogg JC. Pathophysiology of airflow limitation in chronic obstructive pulmonary disease. Lancet 2004;364:709-21.

3. Saetta M, Di Stefano A, Turato G, Facchini FM, Corbino L, Mapp CE, et al. CD8+ T-lymphocytes in peripheral airways of smokers with chronic obstructive pulmonary disease. Am J Respir Crit Care Med 1998;157:822-6.

4. Hodge S, Hodge G, Holmes M, Reynolds PN. Increased airway epithelial and T-cell apoptosis in COPD remains despite smoking cessation. Eur Respir J 2005;25:447-54.

5. Ngan DA, Vickerman SV, Granville DJ, Man SF, Sin DD. The possible role of granzyme B in the pathogenesis of chronic obstructive pulmonary disease. Ther Adv Respir Dis 2009;3:113-29.

6. Buzza MS, Zamurs L, Sun J, Bird CH, Smith AI, Trapani JA, et al. Extracellular matrix remodeling by human granzyme B via cleavage of vitronectin, fibronectin, and laminin. J Biol Chem 2005;280:23549-58. 
7. Hodge S, Hodge G, Nairn J, Holmes M, Reynolds PN. Increased airway granzyme b and perforin in current and exsmoking COPD subjects. COPD 2006;3:179-87.

8. Loebbermann J, Thornton H, Durant L, Sparwasser T, Webster KE, Sprent J, et al. Regulatory T cells expressing granzyme B play a critical role in controlling lung inflammation during acute viral infection. Mucosal Immunol 2012;5:161-72.

9. Kim WD, Eidelman DH, Izquierdo JL, Ghezzo H, Saetta MP, Cosio MG. Centrilobular and panlobular emphysema in smokers. Two distinct morphologic and functional entities. Am Rev Respir Dis 1991;144:1385-90.

10. Kim WD, Chi HS, Choe KH, Oh YM, Lee SD, Kim KR, et al. A possible role for CD8+ and non-CD8+ cell granzyme B in early small airway wall remodelling in centrilobular emphysema. Respirology 2013;18:688-96.

11. Foster WL Jr, Gimenez EI, Roubidoux MA, Sherrier RH, Shannon RH, Roggli VL, et al. The emphysemas: radiologicpathologic correlations. Radiographics 1993;13:311-28.

12. Smith BM, Austin JH, Newell JD Jr, D'Souza BM, Rozenshtein A, Hoffman EA, et al. Pulmonary emphysema subtypes on computed tomography: the MESA COPD study. Am J Med 2014;127:94.

13. Leopold JG, Gough J. The centrilobular form of hypertrophic emphysema and its relation to chronic bronchitis. Thorax 1957;12:219-35.

14. Kim WD, Ling SH, Coxson HO, English JC, Yee J, Levy RD, et al. The association between small airway obstruction and emphysema phenotypes in COPD. Chest 2007;131:1372-8.

15. Eidelman D, Saetta MP, Ghezzo H, Wang NS, Hoidal JR, King $\mathrm{M}$, et al. Cellularity of the alveolar walls in smokers and its relation to alveolar destruction: functional implications. Am Rev Respir Dis 1990;141:1547-52.

16. Finkelstein R, Fraser RS, Ghezzo H, Cosio MG. Alveolar inflammation and its relation to emphysema in smokers. Am J Respir Crit Care Med 1995;152:1666-72.

17. Majo J, Ghezzo H, Cosio MG. Lymphocyte population and apoptosis in the lungs of smokers and their relation to emphysema. Eur Respir J 2001;17:946-53.

18. Saetta M, Baraldo S, Corbino L, Turato G, Braccioni F, Rea F, et al. CD8+ve cells in the lungs of smokers with chronic obstructive pulmonary disease. Am J Respir Crit Care Med 1999;160:711-7.

19. Cosio MG, Saetta M, Agusti A. Immunologic aspects of chronic obstructive pulmonary disease. N Engl J Med 2009;360: 2445-54.

20. Nowacki TM, Kuerten S, Zhang W, Shive CL, Kreher CR, Boehm BO, et al. Granzyme B production distinguishes recently activated CD8(+) memory cells from resting memory cells. Cell Immunol 2007;247:36-48.

21. Wherry EJ, Kurachi M. Molecular and cellular insights into T cell exhaustion. Nat Rev Immunol 2015;15:486-99.

22. Barcelo B, Pons J, Ferrer JM, Sauleda J, Fuster A, Agusti AG. Phenotypic characterisation of T-lymphocytes in COPD: abnormal CD4+CD25+ regulatory T-lymphocyte response to tobacco smoking. Eur Respir J 2008;31:555-62.

23. Lee SH, Goswami S, Grudo A, Song LZ, Bandi V, GoodnightWhite $S$, et al. Antielastin autoimmunity in tobacco smokinginduced emphysema. Nat Med 2007;13:567-9.

24. Hou J, Sun Y, Hao Y, Zhuo J, Liu X, Bai P, et al. Imbalance between subpopulations of regulatory T cells in COPD. Thorax 2013;68:1131-9.

25. Isajevs S, Taivans I, Strazda G, Kopeika U, Bukovskis M, Gordjusina V, et al. Decreased FOXP3 expression in small airways of smokers with COPD. Eur Respir J 2009;33:61-7.

26. Cao X, Cai SF, Fehniger TA, Song J, Collins LI, Piwnica-Worms DR, et al. Granzyme B and perforin are important for regulatory T cell-mediated suppression of tumor clearance. Immunity 2007;27:635-46.

27. Chang WC, Li CH, Huang SC, Chang DY, Chou LY, Sheu BC. Clinical significance of regulatory T cells and CD8+ effector populations in patients with human endometrial carcinoma. Cancer 2010;116:5777-88.

28. Gondek DC, Lu LF, Quezada SA, Sakaguchi S, Noelle RJ. Cutting edge: contact-mediated suppression by CD4+CD25+ regulatory cells involves a granzyme B-dependent, perforinindependent mechanism. J Immunol 2005;174:1783-6.

29. Jahrsdorfer B, Vollmer A, Blackwell SE, Maier J, Sontheimer $\mathrm{K}$, Beyer T, et al. Granzyme B produced by human plasmacytoid dendritic cells suppresses T-cell expansion. Blood 2010; 115:1156-65.

30. Lindner S, Dahlke K, Sontheimer K, Hagn M, Kaltenmeier C, Barth TF, et al. Interleukin 21-induced granzyme B-expressing B cells infiltrate tumors and regulate T cells. Cancer Res 2013;73:2468-79.

31. Arias M, Martinez-Lostao L, Santiago L, Ferrandez A, Granville DJ, Pardo J. The untold story of granzymes in oncoimmunology: novel opportunities with old acquaintances. Trends Cancer 2017;3:407-22.

32. Grossman WJ, Verbsky JW, Tollefsen BL, Kemper C, Atkinson JP, Ley TJ. Differential expression of granzymes A and B in human cytotoxic lymphocyte subsets and T regulatory cells. Blood 2004;104:2840-8.

33. Shresta S, Graubert TA, Thomas DA, Raptis SZ, Ley TJ. Granzyme A initiates an alternative pathway for granule-mediated apoptosis. Immunity 1999;10:595-605.

34. Vernooy JH, Moller GM, van Suylen RJ, van Spijk MP, Cloots $\mathrm{RH}$, Hoet PH, et al. Increased granzyme A expression in type II pneumocytes of patients with severe chronic obstructive pulmonary disease. Am J Respir Crit Care Med 2007;175:46472 . 